\title{
The Idea of Positive Law: Immanuel Kant's Transcendental Argument ${ }^{1}$
}

\author{
Tomasz Bekrycht \\ University of Lodz, Poland \\ tomaszbekrycht@wpia.uni.lodz.pl
}

Received 24 July 2018; accepted 25 January 2019; published 30 June 2019.

\begin{abstract}
In their philosophical projects that address the concept of law, Immanuel Kant, Johann G. Fichte, and Georg W. F. Hegel all employ transcendental argumentation to demonstrate the sovereignty of community and the existence of power. They do this in the attempt to conceptually ground the idea of freedom and reconcile it with the notion of coercion within the framework of the idea of positive law. This article focuses solely on the Kantian project, since the approaches of Fichte and Hegel take on a more speculative turn in addition to their transcendental form.
\end{abstract}

Keywords: positive law; transcendental argumentation; categorical imperative; coercion.

\section{Introduction}

Today it can be said that the transcendental argument for the sovereignty of community and the existence of power, and the attempt to ground the idea of freedom and reconcile it with the notion of coercion within the framework of the concept of positive law, characterizes the classical approach to the transcendental philosophy of Immanuel Kant. ${ }^{2}$

\footnotetext{
${ }^{1}$ The following text was prepared as a part of research grant financed by the National Science Centre (Poland) and titled “Democratic Legitimization of Judicial Rulings' Influence on Law Making” (no. 2015/19/B/HS5/03114).

${ }^{2}$ In this paper I make use of some fragments from my monograph, namely Transcendentalna filozofia prawa: $O$ zewnetrznym obowiazywaniu i uzasadnieniu istnienia prawa (The Transcendental Philosophy of Law: On the External Validity and Justification of the Existence of Law), University of Lodz Press, editorial series "Jurysprudencja", Vol. 6, 2015.
} 
In Kant's philosophy, the theoretical and practical use of reason corresponds with the dual nature of the world, i.e. the world as nature and the world as freedom, and the task of practical reason is to somehow overcome the cognitive limitations of theoretical reason (Kant, 2015, pp. 43-44, AA V, 50-51).

The critique of pure reason demonstrated that freedom is not logically contradictory, proving that it must belong to the sphere of the noumenal reality, the existence of which is the foundation of freedom. Since it is impossible for our theoretical knowledge to access this sphere, freedom is not subject to theoretical proof. However, knowledge of the idea of freedom is a practical necessity for the subject of moral action and, thus, it is not merely an arbitrary invention or a dogmatic premise, but a transcendental concept.

Transcendental freedom has two aspects: negative and positive. The former one is about independence from the laws of nature, while the latter one involves the ability to start a series of events (Wyrębska-Dermanovic, 2018, pp. 25-26). Accordingly:

Due to the clearly non-phenomenal nature of transcendental freedom, Ewa Nowak writes, Kant is forced to accept that the causal agency of freedom is for us - reflective beingssomething that can only be thought: it is an idea. However, this idea is not an empty illusion: on the contrary, it turns out to be so important that within our human world - which is therefore not only empirical but also intellectual — it should be immediately recognized as a 'regulative principle'. (Nowak, 2002, p. 23)

Where does this necessity stem from? Apparently, it comes from something that could be called the 'necessity of the enlightenment' or 'faith in reason', a 'faith' that pulls human beings from the phenomenal world, metaphorically speaking, and, thus, allows them to be responsible for their own actions. Human beings become the source of the law for themselves, because, as Kant writes in The Metaphysics of Morals:

We cannot present theoretically freedom as a noumenon, that is, freedom regarded as the capacity of man merely as an intelligence, and show how it can exercise constraint upon his sensible choice; we cannot therefore present freedom as a positive property. But we can indeed see that, although experience shows that man as a sensible being has the capacity to choose in position to as well in conformity with the law, his freedom as an intelligible being cannot be defined by this, since appearances cannot make any supersensible object (such as free choice) understandable. (Kant, 1991, p. 52, AA VI, 226)

Therefore, Kant set himself the task of establishing the transcendental justification of this problem, i.e. locating the source of the fundamental principles of our moral action in practical reason. In other words, he was committed to revealing the a priori elements of practical reason.

\section{The Autonomy of the Will, the Categorical Imperative, the Idea of Freedom}

The highest principle of practical reason and "the sole principle of all moral laws and of duties in keeping with them" (Kant, 2015, p. 30, AA V, 33) is, according to Kant, the 
autonomy of the will. The autonomy of the will designates the conscious choice of actions not imposed by nature or by any authority.

However, one can ask about how it is that the will obliges itself in the act of determination and, therefore, in the act of a certain, it could be said, coercion. Kant's answer is that this is due to the principle of autonomy. If the will is to act, then it must simultaneously coerce itself. This is the meaning of autonomy: the will is not subject to external coercion, but only to its own, internal coercion. It is a kind of self-determination; pure autonomy. It could be argued that here the objective "I should (ought to)" emerges from the subjective "I want" (Nowak, 2002, p. 42).

According to Frederick Copleston: the autonomy of the will makes it possible to act in accordance with the dictates of reason which are not determined by nature, i.e. the categorical imperative. The categorial imperative obliges the will to act in a certain way. Its purpose is tied to action, to the performance of deeds that are good in themselves, rather than learning about empirical reality, hence it is called a practical synthetic a priori proposition (Copleston, 1994, pp. 331-332). " "The categorical imperative," writes Ewa Nowak, "as a synthetic proposition a priori, binds will with action through unconditional duty" (Nowak, 2002 , p. 32). However, at this point one can ask the question of how such a practical synthetic proposition is possible a priori? In order to answer this question, Kant sought a "third term", which would unite the predicate with the subject, because in synthetic propositions the predicate cannot be extracted from the subject through the analysis itself; there must be a third term that unites them (Copleston, 1994, pp. 332-333).

In other words, in order to establish the possibility of the categorical imperative, Kant had to ask about what makes the principle of autonomy of the will possible. The answer to this is: the idea of freedom. It is in this idea that the condition of the possibility of the categorical imperative can be located. We can only act for the sake of duty, or act morally, if we accept the idea of freedom. Duty (obligation) implies being free; being free to obey or disobey the law. Thus, the acceptance of freedom is a practical necessity for the subject of moral action. As the great philosopher further states:

Thus the question 'How is a categorical imperative possible?' can be answered to this extent: one can state the sole presupposition under which alone it is possible, namely the idea of freedom, and to the extent that one can have insight into the necessity of this presupposition, which is sufficient for the practical use of reason, i.e. for the conviction of the validity of this imperative, hence also of the moral law; but how this presupposition itself is possible, no insight into that can be gained through any human reason. Under the presupposition of freedom of the will, its autonomy, as the formal condition under which alone it can be determined, is a necessary consequence. (Kant, 2002, p. 77, AA IV, 461)

Therefore, to us the idea of freedom appears to be an inalienable idea granted to the human subject. The source of this idea lies in practical reason, which reveals its superiority over theoretical reason. Practical reason extends beyond the limits of theoretical reason, i.e.

\footnotetext{
${ }^{3}$ See Makowski, 2006 for a comprehensive analysis of this issue.
} 
beyond the boundaries of scientific cognition, and discovers freedom as the ability to make decisions on the principles of one's own actions, as well as bear responsibility for them (Kuderowicz, 2000, pp. 61-62). Thus, the practical necessity of the idea of freedom entails understanding oneself as belonging not only to the world of the senses (phenomena), but also to the world of "things in themselves", i.e. the noumena. A human being belonging to the noumenal world asserts that they are subject to laws which have their basis only in reason and, as the author writes:

The idea of freedom makes me into a member of an intelligible world, through which, if I were that alone, all my action would always be accord with the autonomy of the will; but since I intuit myself at the same time as member of the world of sense, they ought to be in accord with it [...]. (Kant, 2002, p. 70, AA IV, 454)

\section{Morality and Positive Law}

Taking all of the above into account, it follows that in the sphere of moral law human beings are the absolute legislators of the rules that determine their behavior, and the subjective assessment of their own actions is made only by moral subjects themselves. However, a problem arises concerning the conformity of the human beings' actions with the moral law as a certain objectified sphere (intersubjective). This issue pertains to the field of knowledge, which Kant calls Tugendlehre, or the doctrine of virtue. That being said, the evaluation of actions from the point of view of the doctrine of virtue is problematic. This is due to the fact that access to the 'thing-in-itself' and, thus, the direct feeling of one's own noumenal nature is not given even to subjects themselves, which is why it is even less possible for the external interference to make such an evaluation, let alone replace it from the point of view of morality. Nevertheless, such an evaluation is and must be made possible, because otherwise all the evil done in the world will have to go unpunished. However, this evaluation will concern not the human being undertaking the action of a moral subject, but the human being as an object (phenomenon) affecting other objects (phenomena), because a human being is not only a free, noumenal subject and the basis of moral legislation, but also a certain object (phenomenon) existing among other objects, including other people (as objects).

The above considerations indicate that actions and their consequences require the division into the internal sphere (individualized moral law) and the external sphere (the functioning of society). Therefore, there are two levels that form the basis of the practical philosophy. At each of them, free subjects exist and act, and the actions of these subjects are assessed differently depending on the level. As a result, two assessment criteria emerge: internal and external. The former one refers to the subjective legislation of every free subject, while the latter one concerns legislation, the task of which is to ensure the proper functioning of society. 
It follows from Kant's moral philosophy that the fundamental and inviolable principle of morality involves absolute respect for the freedom and dignity of other human beings, viewed as ends in themselves and not just as a means for one's actions. In order to fulfill the purpose that moral law sets for human beings (conceived objectively), their actions must be guided by the categorical imperative. To make this possible, human beings must be free, autonomous subjects, because the categorical imperative depends on the idea of freedom. In other words, in order to fulfill the purpose of the moral law, human beings' will must be subjugated to the law of the categorical imperative; according to Kant, it is only then that people are entitled to consider themselves as really free. However, it is easy to imagine a situation in which a subject is, in their actions, guided not by the law of a categorical imperative, but follows a hypothetical imperative instead, e.g. as a result of succumbing to passions. Of course, such a subject is allowed to act this way, because this is their free will, yet such behavior will be judged as immoral, because it is not guided by a command of reason (the categorical imperative).

It should be added and strongly emphasized that, as Andrzej M. Kaniowski writes, these normative requirements are imposed on a human being as a moral being, and these are the requirements that only human beings can impose on themselves; they cannot be imposed on a human being by anyone from outside, i.e. the environment, the society, or the state (Kaniowski, 2004, p. 118).

However, in a situation when the actions of a subject infringe on the sphere of freedom of another subject and interfere with their free will, the common good requires objective norms (objective law) to be called upon in order for the objects-phenomena relationship to be clear and submitted to objective evaluation. Of course, the multiplicity of interests does not necessarily lead to them being in conflict as long as individuals act in accordance with the content of the categorical imperative, i.e. are guided by a general law rather than the ends of their own actions. In other words, it is necessary to "act so that you use humanity, as much in your own person as in the person of every other, always at the same time as end and never merely as means" (Kant, 2002, pp. 46-47, AA IV, 429).

This also leads Kant to formulate the categorical imperative of universal legislation, i.e. the moral community. As he advises, "Act in accordance with that maxim which can at the same time make itself into a universal law" (Kant, 2002, p. 55, AA IV, 436-437).

At this point, however, one can ask the following questions - what exactly do we mean by the law here? Is it something purely subjective or something objective (moral community or intersubjective moral rules), or something that one could call the positive law? It would seem that the notion of the law is ambiguous here and this ambiguity is not properly distinguished by Kant ${ }^{4}$. It seems to me that on the basis of an analysis of Kant's works, one can identify, first, subjective morality (the morality of an individual subject); second, the

\footnotetext{
${ }^{4}$ See Wyrębska-Dermanovic (2018, p. $51 \mathrm{ff}$ ) for an analysis of the notional apparatus of this issue.
} 
morality of the community (intersubjective morality); and, third, positive law as the possibility of realizing the moral rules of a given community. ${ }^{5}$

When making a general classification of rights, Kant writes:

The highest division of rights, as (moral) capacities for putting others under obligations (i.e., as a lawful basis, titulum, for doing so), is the division into innate and acquired right. An innate right is that which belongs to everyone by nature, independently of any act that would establish a right; an acquired right is that for which such and act is required [...]. Freedom (independence from being constrained by another's choice), insofar as it can coexist with the freedom of every other in accordance with universal law, is the only original right belonging to every man by virtue of his humanity. (Kant, 1991, p. 63, AA VI, 237)

At this point, one can also mention the concept of political freedom, which is transcendentally institutionalized in the idea of the state of goals and the idea of eternal peace. This former one is a relationship of intelligent individuals and is created by the law jointly established. The latter one is, in turn, a relationship existing between states. In both cases the law is understood as intersubjective morality with a universal scope and characterized by unprecedented universality. This relationship (the relation of the law), as Marek J. Siemek writes, "originally and in its deepest essence is politics" (Siemek, 1995, p. 109) or even intersubjective "politics" (Siemek, 1995, p. 114). Thus, the notions of community, the law, and politics refer to one another, creating an intersubjective relationship of, first, the moral community and, second, the legal community (positive law).

The Kantian 'state of goals' as the expression of such an intersubjective community of ethical subjects is not just a metaphor. On the contrary, it is only the 'state' character of this community that fully realizes the very essence of human ethics, which is nothing else, but the system of rational freedom built within it. (Siemek, 1995, pp. 113-114)

Therefore, one can say that the moral community constitutes a kind of synthesis of the noumenal and phenomenal spheres. However, what is it that guarantees that moral norms are respected? From the conceptual point of view, a paradoxical situation arises. On the one hand, human beings are convinced that moral norms cannot be enforced, since this would be immoral (infringing on the freedom of another subject), but, on the other hand, the fact is that some subjects do infringe on the freedom of other subjects. With all this said, it seems that if discussing the existence of moral norms in a given community has to

\footnotetext{
${ }^{5}$ I introduced this distinction in the article "Positive Law and Morality - Violence and Coercion" (Bekrycht, 2018). One more normative sphere can be distinguished in Kant's writings, namely natural law, the concept of which was introduced in Metaphysik der Sitten and Zum ewigen Frieden. I leave unresolved the question of whether the sphere of natural law can be interpreted as the morality of the community or whether it is an area between 'morality' and positive law. On a side note, one could also put forward the thesis that in Kant's writings the justification of the moral community, i.e. objective moral rules, appears in his concept of natural law. As Ewa Nowak writes, "There is no need for any additional evidence that the law established without consideration of the universal, well-considered criteria of justice not only allows the mindlessness of legislators to become apparent, but also leads to legalized lawlessness. Furthermore, according to Kant, the law that meets this criterion corresponds to natural law" (Nowak, 2002, p. 116). For more detailed analyses of the concept of natural law and its place in Kant's philosophy, see Bekrycht 2004.
} 
make sense, these norms must also be realized. Thus, what is needed is an organizational principle that could potentially influence the realization of these norms, which, on the one hand, would help build a moral community and, on the other, would grant human beings the freedom not to observe such norms on occasion, because, for example, people maximize their own vision of values that are determined by various factors resulting from the human condition (as noumenon and phenomenon).

In other words, the fact that there are norms resulting from the moral law does not mean that they will always determine the will to obey them, because it is always possible for anyone to not want what they had previously desired. Therefore, human beings would always act according to the norms set by the categorical imperative only if they were free from all empirical tendencies and subjugated to pure practical reason. It can be said that in this case they would cease to be human beings, not only because they were deprived of their inclinations, but, above all, because they were stripped of their will.

However, Kant did not include this dual nature of human beings in his project of justifying morality. Ernst Tugendhat sums up various critiques of the project in which Kant only takes pure practical reason into account. As the former author asks, "Do we not lose this 'maybe', the freedom which is the freedom to be moral or immoral?" (Tugendhat, 1993, pp. 129-131). One could go so far as to say that in this case human beings would entirely lose their objective notion of morality. In this regard, the actual dimension of the operation of the law also needs to be taken into consideration, as well as the idea of the organizational principle needs to be outlined, and it must take not only the normative dimension (binding moral rules) into account, but also the whole issue of the realization of them. Therefore, as a community, the humanity must justify allowing coercion (violence), i.e. the idea of positive law. In other words, when the philosophy of the categorical imperative comes up against real legal obligations, it is simply powerless (Buchner, 1996, p. 68).

This leads to the conclusion that the focus of positive law is the external sphere of the freedom of many individuals, where coercion must arise due to the inevitability of conflicting interests. Kant clearly identifies the concept of positive law with the authorization of coercion. However, this identification is rooted in contradictions. The line of thinking is that if a subject exercises their freedom in a way that cannot be reconciled with the freedom of another subject, then, according to the common law, the action is in contrast to the law. Resistance to unlawful acts that infringe on freedom promotes this freedom and is consistent with it, and so, as Kant states:

If a certain use of freedom is itself a hindrance to freedom in accordance with universal laws (i.e., wrong), coercion that is opposed to this (as a hindering of a hindrance to freedom) is consistent with freedom in accordance with universal laws, that is, it is right. (Kant, 1991, p. 57, AA VI, 231)

It should be noted, however, that Kant's identification is possible only in the relationship between coercion and the law in the strict sense (ius strictum), i.e. positive law, because the notion of Right in the strict sense cannot refer to the consciousness of obligation as a motive determining the will; it is 'pure' and determined only by what is 'external', and, therefore, 
is opposed to the principle of the possibility of using external coercion. Kant illustrates the above argument with the example of a creditor who has the right to demand payment from a debtor; this demand is not based on the fact that an authorized creditor convinces the debtor that their reason obliges them to fulfill the obligation, but, rather, is based on the fact that they have the right to compel the debtor to pay the debt. According to Kant, the right to demand the repayment of debt that is owed to the creditor translates into the possibility of employing external coercion. As the author explains, "Strict Right rests instead on the principle of its being possible to use external constraint that can coexist with the freedom of everyone in accordance with universal laws" (Kant, 1991, p. 57, AA VI, 232).

With regard to the law of reciprocal coercion, which is necessarily consistent with the freedom of all subjects under the principle of universal freedom, Kant says that it is "[...] as it were, the construction of that concept", which is intuited a priori (Kant, 1991, p. 58, AA VI, 232). To justify this position, he employs an analogy to mathematics, because, just as the properties of an object of pure mathematics cannot be derived directly from the concepts of mathematics itself, but only through the construction of these concepts, human beings discover the concept of right (in the sense of positive law) only through its construction, thus " $[\ldots]$ it is not so much the concept of Right as rather a fully reciprocal and equal coercion brought under a universal law and consistent with it, that makes the presentation of that concept possible" (Kant, 1991, p. 58, AA VI, 232). Therefore, this external legal constraint comes from general rationality as a possibility, i.e. a certain potential that can be realized towards fellow citizens.

\section{Conclusion}

All the above considerations make it clear that, first, the normative spheres of subjective morality (the moral rules of a given subject), the morality of the community (objectified moral rules), and positive law all refer to the idea of freedom, i.e. the recognition of the human being as a subject who takes responsibility for their own actions. The moral responsibility of a subject covers the sphere of motivation and the choice of the maxim of conduct, whereas legal responsibility (both in the sense of objective moral rules and with regard to the norms of positive law) refers to the effects of the action and its impact on other subjects.

Second, a conceptually important issue arises here regarding the reciprocal relationship between the three normative spheres distinguished above, which Ewa Nowak emphasizes very clearly by saying what follows:

Although the concept of a moral community has nothing in common with the concept of a legal-civic community, it is worth realizing that the connection between them, or-to be more precise - what constitutes the basis of the legislative procedure common to both (moral or juridical), is the formal principle of duty, or the categorical imperative. (Nowak, 2002, p. 62)

The imperative requires that human beings treat their own freedom and that of others as an end in itself, never as a means, i.e. instrumentally, as an object. Objectified moral rules 
(the morality of the community) and positive law both concern only the external sphere, understood as the sphere in which individuals interact reciprocally, and freedoms can be in conflict with each other due to the finite nature of the world (there is simply no room for unlimited claims of freedom). Therefore, it is necessary to develop the concept of the moral community as objectified moral principles and the concept of positive law, since these normative systems will regulate the external manifestation of the innate inclination of human beings towards evil, i.e. towards activities that might have a negative impact on the actions of other individuals. The task of positive law is to establish norms like these and to secure them with the sanction of coercion so that the individual's actions do not lead to effects that constitute an infringement on other individuals' freedom.

The following reflections seem to be in order when trying to sum up all the considerations above. The history of the modern societies of the Occidental culture shows that with the blurring of the classic difference between the public and the private, and the development of the social sphere understood as a community of families, the idea of freedom clashed with the idea of the necessity of dealing with members of society understood as an indivisible whole; it could be argued that, to some extent, these two ideas intermingled (Arendt, 1998, pp. 22-78). A problem arose that, among others, Immanuel Kant attempted to solve, namely how to restore the idea of freedom in the sphere in which arbitrariness prevails. In other words, how to reconcile the freedom of every human being with the freedom of other people? In principle, it can be said that such a reconciliation is inconceivable without excluding that which is necessary, i.e. naturalistic determinism, from the public sphere.

This is clearly seen in Marek J. Siemek's analysis of the concept of political freedom in Kant's writings. Interpreting the great philosopher's ethics, Siemek advances a very interesting thesis, namely that "unlike the traditional ethics of happiness, love or compassion, Kant's transcendental philosophy creates the first consistent and coherent project of modern ethics and justice" (Siemek, 1995, p. 117). Therefore, Kant's ethics has a political grounding, which is expressed in the ideas of 'the state of goals' and 'the eternal peace'. As the former author continues:

The Kantian 'state of goals' as a model of the intersubjective system of ethical freedom has its roots not so much in the Christian ideal of a purely moral 'community of souls' consolidated by love and faith, but rather in the Greek ethos of koinonia politike or the Roman res publica. Kant was concerned with autonomy, which is also an isonomy-a self-regulating principle of a rational community of free and equal subjects, remaining in a communicational relation of reciprocity, i.e. symmetrical and equivalent, i.e. just a fair exchange of their freedom and subjectivity [...]. (Siemek, 1995, p. 117)

Such a reconciliation is only conceivable in a public sphere based on action rather than behavior. This was the case in the Greek polis, where the few members of society who were viewed as equals competed in the public sphere in order to distinguish themselves from their peers through their actions. As a result:

The public realm $[\ldots]$ was reserved for individuality; it was the only place where men could show who they really and inexchangeably were. It was for the sake of this chance, and out 
of love for a body politic that made it possible to them all, that each was more or less willing to share in the burden of jurisdiction, defense, and administration of public affairs. (Arendt, 1998, p. 41)

Therefore, when developing the conception of the moral community and positive law today (as the sphere in which the community's norms are to be realized), one is obliged to conceive of the behavior of citizens as being subject to coercion, i.e. something that prevailed in the private sphere of the Greeks.

The gradual blurring of the difference between the two public and the private has led to coercion permeating the political life. The concept of power took on the characteristics of violence, thereby hindering the understanding of issues associated with the justification of positive law, which came to be identified with the use of force and submission to the model of biological relations, in which there is no room for freedom.

\section{References}

Arendt, H. (1998). The Human Condition. Chicago, IL: The University of Chicago Press.

Bekrycht, T. (2004). Kant: Die Kritik der Konzeption des Naturrechts. In T. Machalova (Ed.), Pravne filosoficky odkaz I: Kanta a soucasne pravni mysleni (p. 40-47). Brno, The Czech Republic: Masarykova Univerzita v Brne.

Bekrycht, T. (2015). Transcendentalna filozofia prawa: O zewnętrznym obowiąywaniu I uzasadnieniu istnienia prawa. Łódź, Poland: Wydawnictwo Uniwersytetu Łódzkiego.

Bekrycht, T. (2018). Positive Law and Morality: Violence and Coercion. Journal of the University of Latvia "Law", 2018(11), 6-12. Retrieved from https://www.journaloftheuniversityoflatvialaw.lu.lv/fileadmin/user_upload/lu_portal/projekti/journaloftheuniversityoflatvialaw/No11/T_Tomasz_Bekrycht.pdf

Buchner, W. (1996). Kant: Państwo i prawo. Kraków, Poland: Aureus.

Copleston, F. (1994). A History of Philosophy, vol. VI. Modern Philosophy: From the French Enlightenment to Kant. New York, NY: Image Book.

Kaniowski, A. M. (2004). Filozofia praktyczna Immanuela Kanta: Jej siła i słabość. Diamatros (2), 114-126.

Kant, I. (1991). The Metaphysic of Morals. (M. Gregor, Transl.). Cambridge, UK: Cambridge University Press.

Kant, I. (2002). Groundwork for the Metaphysics of Morals. (A. W. Wood, Transl.). New Haven, CT: Yale University Press.

Kant, I. (2015). Critique of Practical Reason. (M. Gregor, Transl.). Cambridge, UK: Cambridge University Press.

Kuderowicz, Z. (2000). Kant. Warszawa, Poland: Wiedza Powszechna.

Makowski, P. (2006). Autonomia w etyce I. Kanta. Diametros (10), 34-64. 
Nowak, E. (2002). Autonomia jako zasada etyczności: Kant, Fichte, Hegel. Wrocław, Poland: Wydawnictwo Uniwersytetu Wrocławskiego.

Siemek, M. J. (1995). Projekt „Wiecznego pokoju” a Kantowski etos nowoczesnej wolności politycznej. In J. Garewicz \& B. Markiewicz (Eds.), Projekt wiecznego pokoju: W 200-lecie wydania pracy Kanta (p. 108-120). Warszawa, Poland: Wydawnictwo Polskiego Towarzystwa Filozoficznego.

Tugendhat, E. (1993). Vorlesungen über Ethik. Berlin, Germany: Suhrkamp.

Wyrębska-Dermanovic, E. (2018). Filozofia prawa Immanuela Kant: Wprowadzenie. Łódź, Poland: Wydawnictwo Uniwersytetu Łódzkiego. 